UNITED STATES DEPARTMENT OF THE INTERIOR

GEOLOGICAL SURVEY

\title{
Analytical results and sample locality map of stream-sediment and heavy-mineral-concentrate samples from the \\ Snowbank Roadless study Area, Valley and Gem Counties, Idaho
}

By

John H. Bullock, Jr.*, Harley D. King*, R.T. Hopkins, Jr.* J.M. Motooka*, Phil L. Hageman*, and B.H. Roushey*

Open-File Report 91- 368 A Paper version 368 B Diskette version

This report is preliminary and has not been reviewed for conformity with U.S. Geological Survey editorial standards and stratigraphic nomenclature. Any use of trade names is for descriptive purposes only and does not imply endorsement by the USGS .

* U.S. Geological Survey, DFC, Box 25046, MS 973, Denver, CO 80225 
Studies related to wilderness . . . . . . . . . . . . . . 1

Introduction . . . . . . . . . . . . . . . . . . . . . . . 1

Methods of study . . . . . . . . . . . . . . . . . 3

Sample media . . . . . . . . . . . . . . . . . 3

Sample collection . . . . . . . . . . . . . . . . 3

Stream-sediment samples. . . . . . . . . . . 3

Heavy-mineral-concentrate samples . . . . . . . 3

Sample preparation . . . . . . . . . . . . . . . . 3

Sample analysis . . . . . . . . . . . . . . . . 5

Spectrographic method . . . . . . . . . . . 5

Other methods . . . . . . . . . . . . . . . 5

Data storage system . . . . . . . . . . . . . . . . . . 6

Description of data tables . . . . . . . . . . . . . 6

Acknowledgments . . . . . . . . . . . . . . . . . . . 6

References cited . . . . . . . . . . . . . . . . . . 7

\section{ILLUSTRATIONS}

Figure 1. Location of the Snowbank Roadless Study Area,

Valley and Gem Counties, Idaho . . . . . . . . . . . . 2

Figure 2. Localities of stream-sediment and heavymineral-concentrate samples from the Snowbank

Roadless Study Area, Valley and Gem Counties, Idaho . . 4

\section{TABLES}

Table 1. Limits of determination for spectrographic analyses of stream-sediment and heavy-mineralconcentrate samples from the Snowbank Roadless Study Area, Valley and Gem Counties, Idaho . . . . . . . 9

Table 2. Other methods used . . . . . . . . . . . . 10

Table 3. Results of analyses of stream-sediment samples . . 11

Table 4 . Results of analyses of heavy-mineral-concentrate samples . . . . . . . . . . . . . . . . . 12 


\section{STODIES RELATED TO WILDERNESS}

The Wilderness Act (Public Law 88-577, September 3, 1964) and related acts requires the U.S. Geological Survey and the U.S. Bureau of Mines to survey certain areas on Federal lands to determine their mineral resource potential. Results must be made available to the public and be submitted to the President and the Congress. This report presents the results of a geochemical survey of the Snowbank Roadless Study Area (RSA) in the Boise National Forest, Valley and Gem Counties, Idaho. The Snowbank Roadless Area was classified as a further planning area during the Second Roadless Area Review and Evaluation (RARE II) by the U.S. Forest Service, January 1979.

\section{INTRODUCTION}

In August, 1990, the U.S. Geological Survey conducted a reconnaissance geochemical survey of the snowbank Roadless Study Area, Valley and Gem Counties, Idaho.

The Snowbank Roadless Study Area comprises about $14.5 \mathrm{sq} \mathrm{mi}$ $(37.8 \mathrm{~km})$ along the southwest side of Valley County, and in the northern tip of Gem County, and lies about $4 \mathrm{mi}(6.4 \mathrm{~km})$ west of Cascade (see fig. 1). Access to the study area is provided on the east by several roads which lead off the gravel road that follows the western shore of Cascade Reservoir, and on the south to southwest by the road to the radio tower on snowbank Mountain.

The study area is situated on a westward tilted fault block that is a part of a north-trending belt, about $30 \mathrm{mi}$ (48 $\mathrm{km}$ ) wide, of normal faults and monoclines coincident with the western border zone of the middle Cretaceous Idaho Batholith (Hamilton, 1962). Much of the study area is on the imposing east-facing scarp of the fault block. The study area is underlain in the southern half chiefly by hornblende gneiss, and in the northern half by grandiorite and quartz diorite gneiss of the Atlanta lobe of the Idaho batholith, which are overlain by Tertiary Columbia River Basalt along the western side of the study area (Mitchell and Bennett, 1979). Plutonic rocks of Cretaceous age in the At lanta lobe of the Idaho batholith have been described by Kiilsgaard and Lewis (1985), and by Lewis and others (1987).

The topographic relief of the study area is about $2,300 \mathrm{ft}$ $(701 \mathrm{~m})$, with a maximum elevation of about $8,320 \mathrm{ft}(2,536 \mathrm{~m})$ at the summit of Snowbank Mountain. The main topographic features of the study area are the north-south trending ridge which extends the length of the study area and the steep, and in places, very rugged east-facing slope. Somewhat parallel, northeast flowing streams have carved valleys in the eastern slope which increase in size and depth towards the southern end of the study area. Summers are warm and dry; most precipitation falls in winter as snow. 


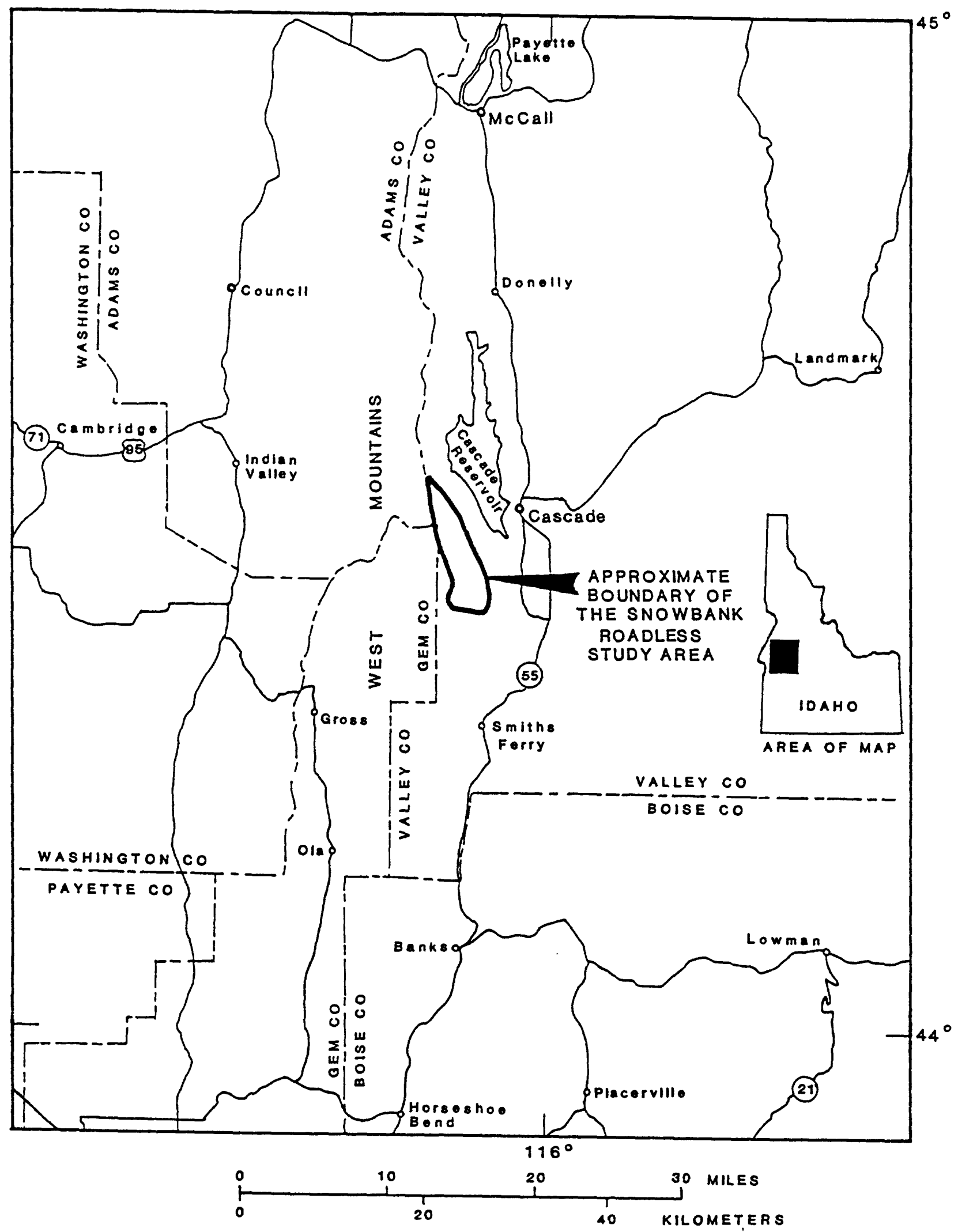

Figure 1. Location of the Snowbank Roadless Study Area, Valley and Gem Counties, Idaho. 


\section{METHODS OF STODY}

\section{Sample Media}

Analyses of the stream-sediment samples represent the chemistry of the rock material eroded from the drainage basin upstream from each sample site. Such information is useful in identifying those basins which contain concentrations of elements that may be related to mineral deposits.

Heavy-mineral-concentrate samples provide information about the chemistry of a limited number of minerals in rock material eroded from the drainage basin upstream from each sample site. The selective concentration of minerals, many of which may be ore related, permits determination of some elements that are not easily detected in stream-sediment samples.

\section{Sample Collection}

Samples were collected at a total of 12 sites (fig. 2). At all sites, both a stream-sediment sample and a heavy-mineralconcentrate sample were collected. Sampling density was about one sample site per 1.2 square miles. The area of the drainage basins sampled ranged from 0.3 to 5.5 square miles. Sufficient heavy-mineral-concentrate for spectrographic analysis (5 mg) was recovered from all sample sites.

\section{stream-sediment samples}

The stream-sediment samples consisted of active alluvium collected primarily from first-order (unbranched) and secondorder (below the junction of two first-order) stream as shown on USGS topographic maps (scale $=1: 24,000)$. Each sample was composited from several localities within an area that may extend as much as 50 feet from the center of the site symbol plotted on the map.

\section{Heavy-mineral-concentrate samples}

Heavy-mineral-concentrate samples were collected from the same active alluvium as the stream-sediment samples. Each bulk sample was screened with a $2.0-\mathrm{mm}$ (10-mesh) screen to remove the coarse material. The less than 2.0-mm fraction was panned until most of the quartz, feldspar, organic material, and clay-sized material were removed.

\section{Sample Preparation}

The stream-sediment samples were air dried, then sieved using 80-mesh $(0.17-\mathrm{mm})$ stainless-steel sieves. The portion of the sediment passing through the sieve was saved for analysis. 


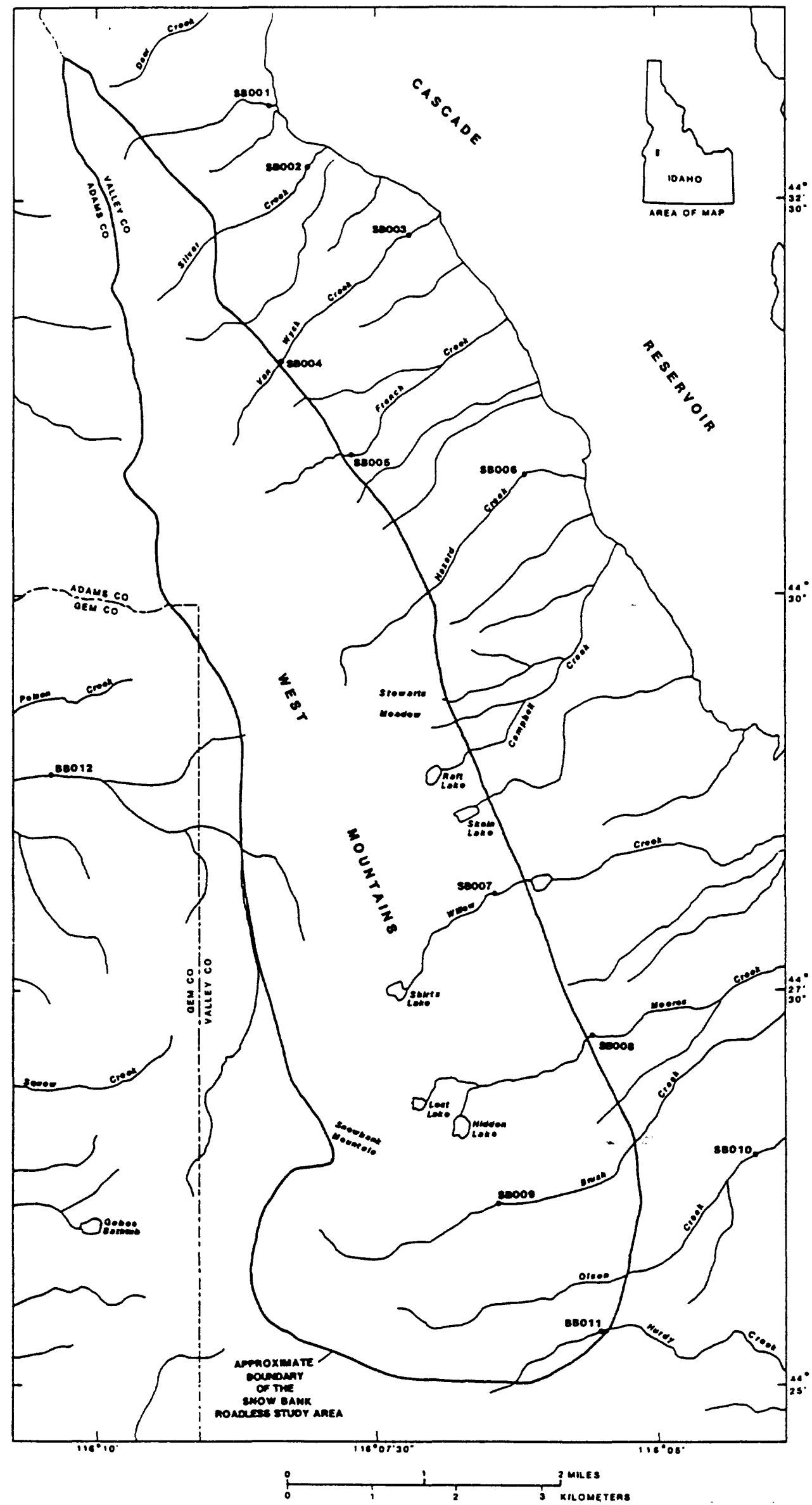

Figure 2. Localities of stream-sediment and heavy-mineralconcentrate samples from the Snowbank Roadless Study Area, Valley and Gem counties, Idaho. 
Samples that had been panned in the field were air dried and sieved to -35 mesh; bromoform (specific gravity 2.85) was used to remove the remaining quartz and feldspar. The resultant heavymineral sample was separated into three fractions using a large electromagnet by placing the sample in contact with the face of the magnet (in this case a modified Frantz Isodynamic Separator). The most magnetic material (removed at a setting of 0.25 ampere), primarily magnetite, was not analyzed. The second fraction (removed at a setting of 1.75 ampere), largely ferromagnesium silicates and iron oxides, was saved for archival storage. The third fraction (the nonmagnetic material which may include the nonmagnetic ore minerals, zircon, sphene, etc.) was split using a Jones splitter. One split was hand ground for spectrographic analysis; the other split was saved for mineralogical analysis. (These magnetic separates are the same separates that would be produced by using a Frantz Isodynamic Separator set at a slope of 15 degrees and a tilt of 10 degrees with a current of 0.2 ampere to remove the magnetite and ilmenite, and a current of 0.6 ampere to split the remainder of the sample into paramagnetic and nonmagnetic fractions.)

\section{Sample Analysis}

\section{Spectrographic method}

Stream-sediment and rock samples were analyzed for 35 elements using a semiquantitative, direct-current arc emission spectrographic method (Grimes and Marranzino, 1968). Heavymineral-concentrate samples were analyzed for those 35 elements plus platinum and palladium. The elements analyzed and their lower limits of determination are listed in table 1. Spectrographic results were obtained by visual comparison of spectra derived from the sample against spectra obtained from standards made from pure oxides and carbonates. Standard concentrations are geometrically spaced over any given order of magnitude of concentration as follows: 100, 50, 20, 10, and so forth. Samples whose concentrations are estimated to fall between those values are assigned values of $70,30,15$, and so forth. The precision of the analytical method is approximately plus or minus one reporting interval at the 83 percent confidence level and plus or minus two reporting intervals at the 96 percent confidence level (Motooka and Grimes, 1976). Values determined for the major elements (iron, magnesium, calcium, sodium, phosporus, and titanium) are given in weight percent; all others are given in parts per million (micrograms/gram). Analytical data are listed in tables 3 and 4.

\section{Other methods}

The stream-sediment samples from the RSA were also analyzed by inductively coupled plasma atomic emission spectroscopy (ICPAES) and atomic absorption spectroscopy (AA). Silver (Ag), 
arsenic (As), gold (Au), bismuth (Bi), cadmium (Cd), copper (Cu), molybdenum (Mo), lead ( $\mathrm{Pb})$, antimony $(\mathrm{Sb})$, and zinc ( $\mathrm{Zn}$ ) were analyzed by ICP (Motooka, 1988), and gold (Au) and mercury (Hg) were analyzed by AA. Limits of determination and references are listed in table 2. Analytical results using these methods are listed in table 3 .

\section{DATA STORAGE SYSTEM}

Upon completion of all analytical work, the analytical results were entered into a U.S. Geological Survey computer data base called PLUTO. This data base contains both descriptive geological information and analytical data. Any or all of this information may be retrieved and converted to a binary form (STATPAC) for computerized statistical analysis or publication (Van Trump and Miesch, 1977).

\section{DESCRIPTION OF DATA TABLES}

Tables 3 and 4 list the results of analyses for the streamsediment and heavy-mineral-concentrate samples, respectively. For these tables, the data are arranged so that column 1 contains the USGS-assigned sample numbers. These numbers correspond to the numbers shown on figure 2. Columns in which the element headings show the letter "s" following the element symbol indicate emission spectrographic analyses, "icp" indicates inductively couple plasma analyses, and "aa" indicates atomic absorption analyses. A letter "N" in the tables indicates that a given element was looked for but not detected at the lower limit of determination (LLD) shown for that element in table 1 . For emission spectrographic and AA analyses, a "less than" symbol (<) entered in the tables in front of the LLD indicates that an element was observed but was below the lowest reporting value. If an element was observed but was above the highest reporting value, a "greater than" symbol ( $>$ ) was entered in the tables in front of the upper limit of determination. If an element was not looked for in a sample, two dashes (--) are entered in the tables in place of the analytical value. Because of the formatting used in the computer program that produced the data tables, some of the elements listed in these tables ( $\mathrm{Fe}, \mathrm{Mg}, \mathrm{Ca}, \mathrm{Ti}, \mathrm{Ag}$, and $\mathrm{Be}$ ) may carry one or more nonsignificant digits to the right of the significant digits. The analysts did not determine these elements to the accuracy suggested by the extra zeros.

\section{ACKNOWLEDGMENTS}

The authors wish to thank Anthony Caldanaro and James Rothgeb for their assistance in the collection of these samples. 


\section{REFERENCES CITED}

Grimes, D.J., and Marranzino, A.P., 1968, Direct-current arc and alternating-current spark emission spectrographic field methods for the semiquantitative analysis of geologic materials: U.S. Geological Survey Circular 591, 6 p.

Hamilton, Warren, 1962, Late Cenozoic structure of west-central Idaho: Geological Society of America Bulletin, v. 73, p. 511-516.

Kiilsgaard, T.H., and Lewis, R.S., 1985, Plutonic rocks of Cretaceous age and faults in the Atlantic lobe of the Idaho batholith, Challis quadrangle, in McIntyre, D.H., editor, Symposium on the Geology and Mineral Deposits of the Challis 1 x 2 degree Quadrangle, Idaho: U.S. Geological Survey Bulletin $1658 \mathrm{~A}-\mathrm{S}, \mathrm{p} .29-42$.

Koirtyohann, S.R., and Khalil, Moheb, 1976, Variables in the determination of mercury by cold vapor atomic absorption: Analytical Chemistry, 48, p. 136-139.

Lewis, R.S., Kiilsgaard, T.H., Bennett, E.H., and Hall, W.E., 1987, Lithologic and chemical characteristics of the central and southeastern part of the southern lobe of the Idaho batholith, in Vallier, T.L., and Brooks, H.C., editors, Geology of the Blue Mountains Region of Oregon, Idaho, and Washington: The Idaho Batholith and its Border Zone: U.S. Geological Survey Professional Paper 1436, p. 171-196.

Mitchell, V.E., and Bennett, E.H., compilers, 1979, Geologic map of the Baker quadrangle, Idaho: Idaho Bureau of Mines and Geology Geologic Map Series, Baker 1 x 2 degree quadrangle, scale $1: 250,000$.

Motooka, J.M., and Grimes, D.J., 1976, Analytical precision of one-sixth order semiquantitative spectrographic analyses: U.S. Geological Survey Circular 738, 25 p.

Motooka, J.M., 1988, An exploration geochemical technique for the determination of preconcentrated organometallic halides by ICP-AES: Applied Spectroscopy, V. 42, no. 7, p. 1293-1296.

O'Leary, R.M., and Meier, A.L., 1986, Analytical methods used in geochemical exploration, 1984: U.S. Geological Survey Circular 948, $48 \mathrm{p}$.

Thompson, C.E., Nakagawa, H.M., and Van Sickle, G.H., 1968, Rapid analysis for gold in geologic materials, in Geological Survey research 1968: U.S. Geological Survey Professional Paper 600-B, p. B130-B132. 
Van Trump, George, Jr., and Miesch, A.T., 1977, The U.S. Geological Survey RASS-STATPAC system for management and statistical reduction of geochemical data: Computers and Geosciences, v. 3, p. 475-488. 
Table 1.--Limits of determination for spectrographic analyses of stream-sediment and heavy-mineral-concentrate samples from the Snowbank Roadless Study Area, Valley and Gem Counties, Idaho

[The spectrographic limits of determination for heavy-mineral-concentrate samples are based on a 5-mg sample, and are therefore two reporting intervals nigher than the limits listed, except as noted

\begin{tabular}{lcc}
\hline \multicolumn{1}{c}{ Elements } & Lower determination limit & Upper determination limit \\
\hline & Weight percent & \\
\hline Calcium $(\mathrm{Ca})$ & 0.05 & 20 \\
Iron ( $\mathrm{Fe}$ ) & .05 & 20 \\
Magnesium $(\mathrm{Mg})$ & .02 & 10 \\
Sodium $(\mathrm{Na})$ & .2 & 5 \\
Phosphorus $(\mathrm{P})$ & .2 & 10 \\
Titanium (Ti) & .002 & 1 \\
\hline
\end{tabular}

Parts per million

\begin{tabular}{|c|c|c|}
\hline $\begin{array}{l}\text { Silver (Ag) } \\
\text { Arsenic (As) } \\
\text { Gold (Au) } \\
\text { Boron (B) } \\
\text { Barium (Ba) } \\
\text { Beryllium (Be) } \\
\text { Bismuth (Bi) } \\
\text { Cadmium (Cd) } \\
\text { Cobalt (CO) } \\
\text { Chromium (Cr) } \\
\text { Copper (Cu) } \\
\text { Gallium (Ga) } \\
\text { Germanium (Ge) } \\
\text { Lanthanum (La) } \\
\text { Manganese (Mn) } \\
\text { Molybdenum (Mo) } \\
\text { Niobium (Nb) } \\
\text { Nickel (Ni) } \\
\text { Lead (Pb) } \\
\text { Antimony (Sb) } \\
\text { Scandium (SC) } \\
\text { Tin (Sn) } \\
\text { Strontium (Sr) } \\
\text { Thorium (Th) } \\
\text { Vanadium (V) } \\
\text { Tungsten (W) } \\
\text { Yttrium (Y) } \\
\text { Zinc (Zn) } \\
\text { Zirconium ( }(\mathrm{Ir} \text { ) } \\
\text { Palladium (Pd)* } \\
\text { Platinum (Pt)* }\end{array}$ & $\begin{array}{c}0.5 \\
200 \\
10 \\
10 \\
20 \\
1 \\
10 \\
20 \\
10 \\
10 \\
5 \\
5 \\
10 \\
50 \\
10 \\
5 \\
20 \\
5 \\
10 \\
100 \\
5 \\
10 \\
100 \\
100 \\
10 \\
20 \\
10 \\
200 \\
10 \\
5 \\
20\end{array}$ & $\begin{array}{r}5,000 \\
10,000 \\
500 \\
2,000 \\
5,000 \\
1,000 \\
1,000 \\
500 \\
2,000 \\
5,000 \\
20,000 \\
500 \\
100 \\
1,000 \\
5,000 \\
2,000 \\
2,000 \\
5,000 \\
20,000 \\
10,000 \\
100 \\
1,000 \\
5,000 \\
2,000 \\
10,000 \\
10,000 \\
2,000 \\
10,000 \\
1,000 \\
1,000 \\
1,000\end{array}$ \\
\hline
\end{tabular}

*Determined in heavy-mineral-concentrate samples only. Limits are for heavymineral-concentrate samples. 
Table 2.--Other methods used

[AA, atomic absorption spectroscopy; ICP, inductively coupled plasma emission spectroscopy; ss, stream-sediment]

\begin{tabular}{|c|c|c|c|c|}
\hline $\begin{array}{l}\text { Element } \\
\text { determined }\end{array}$ & $\begin{array}{l}\text { Sample } \\
\text { type }\end{array}$ & Method & $\begin{array}{l}\text { LLD } \\
\text { (PPM) }\end{array}$ & References \\
\hline $\begin{array}{l}\text { Silver (Ag) } \\
\text { Arsenic (As) } \\
\text { Gold (Au) } \\
\text { Bismuth (Bi) } \\
\text { Cadmium (Cd) } \\
\text { Copper (Cu) } \\
\text { Molybdenum (Mo) } \\
\text { Lead (Pb) } \\
\text { Antimony (Sb) } \\
\text { Zinc ( } \mathrm{Zn})\end{array}$ & $\begin{array}{l}\text { ss } \\
\text { do } \\
\text { do } \\
\text { do } \\
\text { do } \\
\text { do } \\
\text { do } \\
\text { do } \\
\text { do } \\
\text { do }\end{array}$ & $\begin{array}{l}\text { ICP } \\
\text { do } \\
\text { do } \\
\text { do } \\
\text { do } \\
\text { do } \\
\text { do } \\
\text { do } \\
\text { do } \\
\text { do }\end{array}$ & $\begin{array}{l}0.045 \\
0.6 \\
0.15 \\
0.6 \\
0.03 \\
0.03 \\
0.09 \\
0.6 \\
0.6 \\
0.03\end{array}$ & Motooka, 1988. \\
\hline Gold $(\mathrm{Au})$ & do & $A A$ & 0.05 & $\begin{array}{l}\text { Thompson and others, } \\
\text { 1968; O'Leary and } \\
\text { Meier, 1986. }\end{array}$ \\
\hline Mercury (Hg) & do & $\mathrm{AA}$ & 0.02 & $\begin{array}{l}\text { Koirtyohann and } \\
\text { Khalil, } 1976 .\end{array}$ \\
\hline
\end{tabular}


TABLE 3--ANALYTICAL RESULTS OF STREAM-SEDIMENT SAMPLES FROM THE SNOWBANK ROADLESS STUDY AREA, VALLEY COUNTY, IDAHO.

$[N$, not detected; <, detected but below the limit of determination shown; >, determined to be greater than the value shown.]

Sample Latitude Longitude Ca-pct. Fe-pct. Mg-pct. Na-pct. P-pct. Ti-pet. Ag-ppm As-ppm Au-ppm

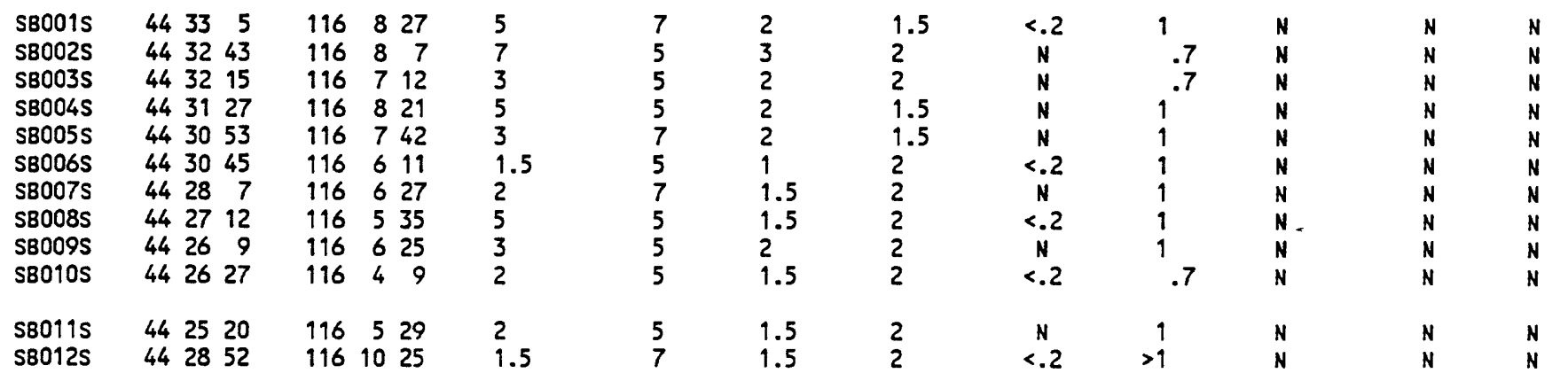

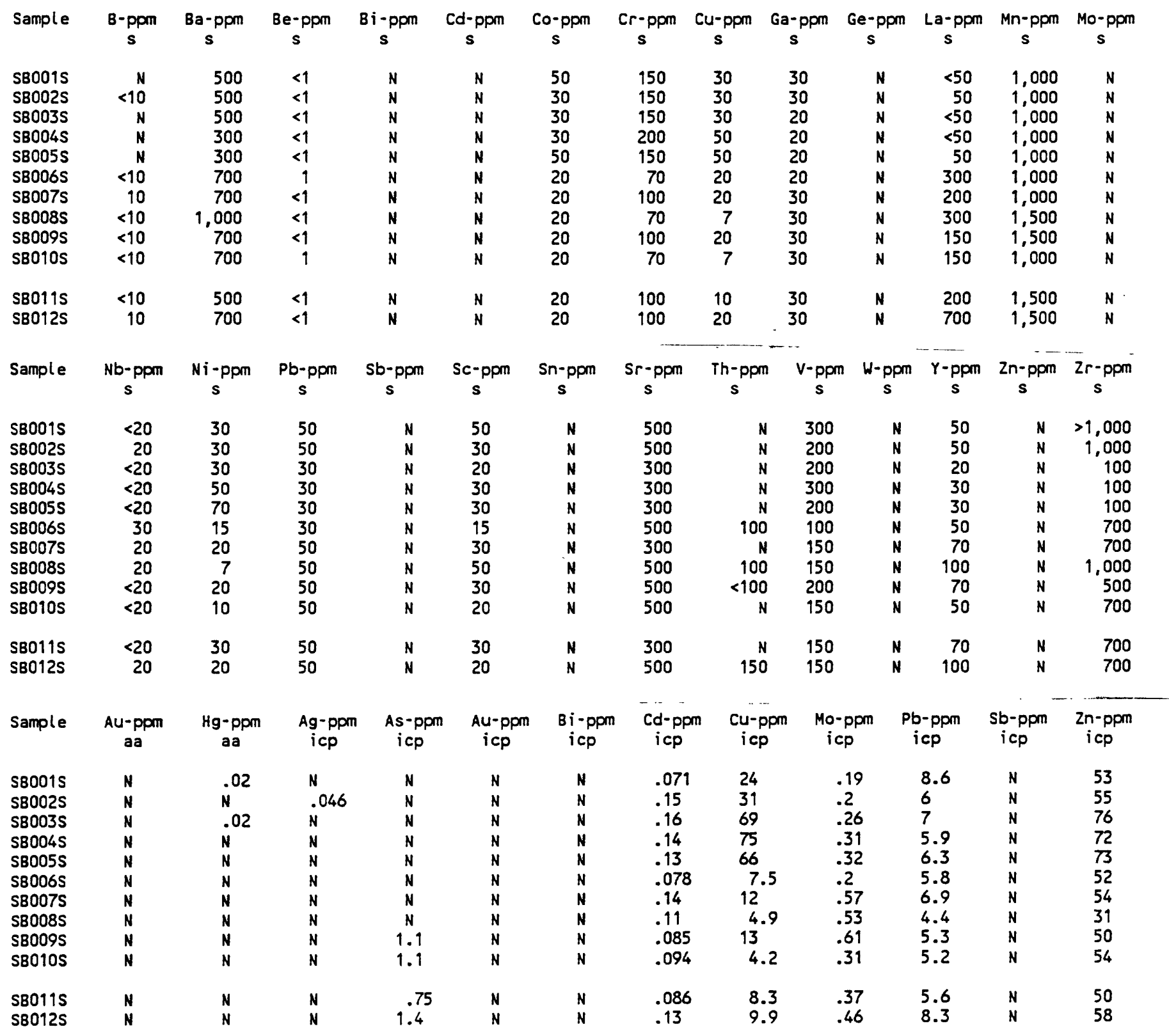


TABLE 4--ANALYTICAL RESULTS OF HEAVY-MINERAL-CONCENTRATE SAMPLES FROM THE SNOWBANK ROADLESS STUDY AREA, VALLEY COUNTY, IDAHO.

$N$, not detected; <, detected but below the limit of determination shown; >, determined to be greater than the value shown.]

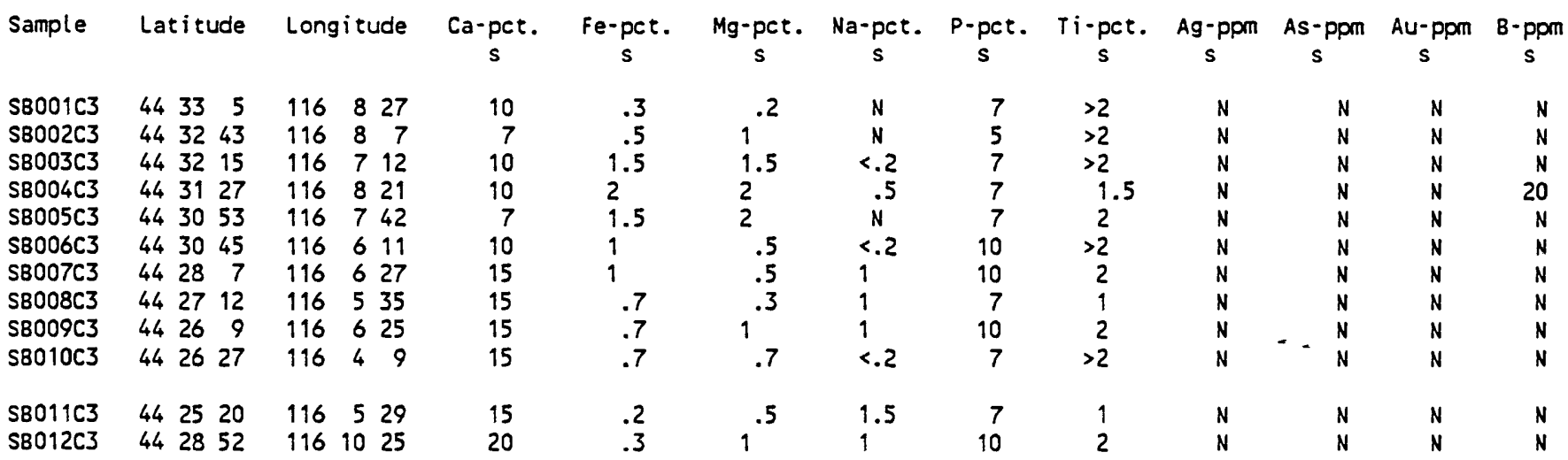

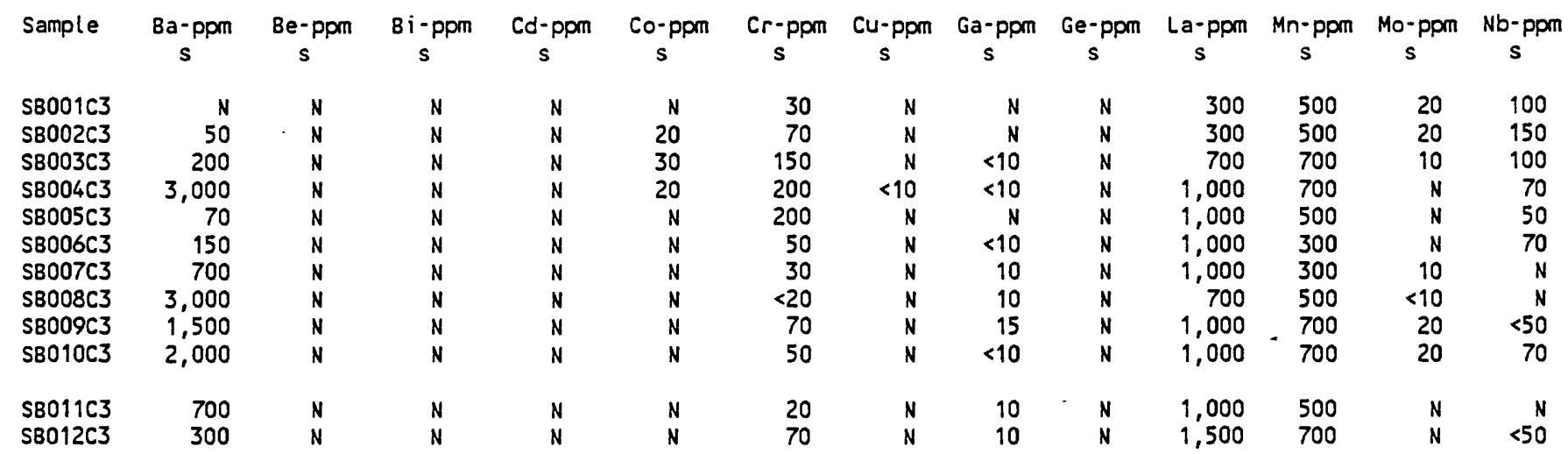

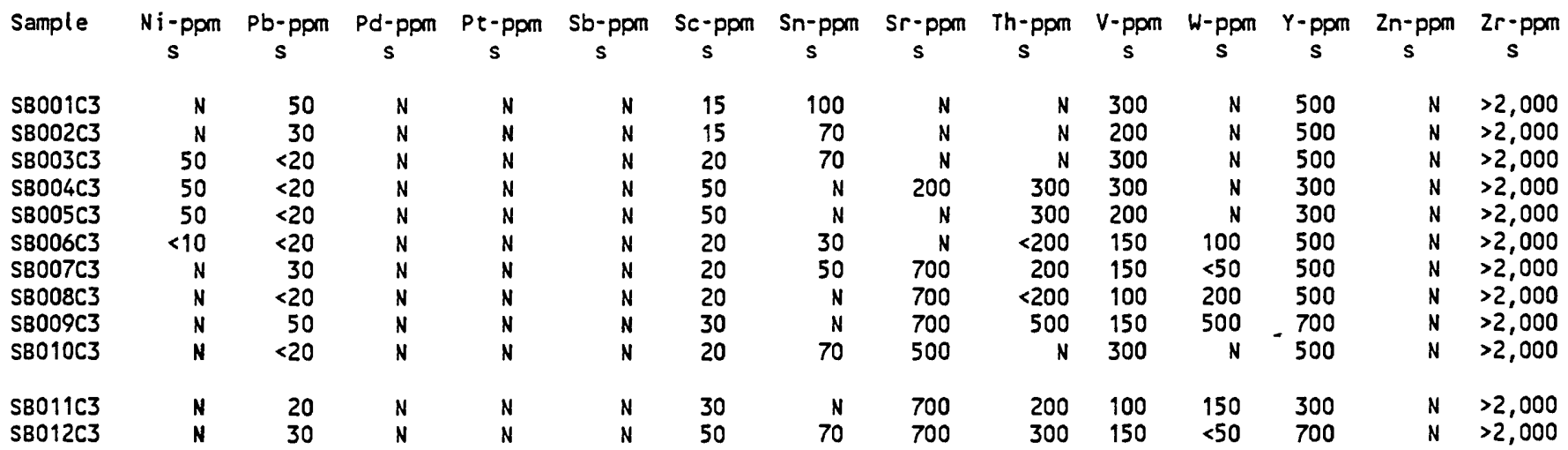

